\section{Phosphorylation of Myosin by Adenosine Triphosphate}

THE study of the interaction between actomyosin and adenosine triphosphate has hitherto given evidence of physical changes in the protein and of its enzymic activity. Very little was known, however, of chemical changes in the protein molecule accompanying the physical effects. Phosphorylation of the protein $^{1}$ and formation of an adenosine triphosphateprotein compound ${ }^{2}$ have been suggested as alternative possibilities, but conclusive experimental evidence has not yet been presented. cause orthophosphate is quantitatively removed by the washing preceding denaturation.

While phosphorylation and nucleotide uptake are independent of the enzymic activity of the protein, a close correlation exists between chemical effects and constriction of volume. Both phenomena require the presence of adenosine triphosphate, which is highly specific for both reactions. In increasing concentrations adenosine triphosphate causes increasing phosphorylation and nucleotide uptake as well as increasing volume constriction. Addition of magnesium salts, which enhances the latter effect, also increases phosphorylation.

Content in phosphate and adenine ( $\mu \mathrm{gm} . / \mathrm{gm}$. threads)

\begin{tabular}{|c|c|c|c|c|c|c|c|c|c|c|c|c|c|c|c|}
\hline \multicolumn{3}{|c|}{ Temperature } & \multicolumn{6}{|c|}{$0^{\circ} \mathrm{C}$} & \multicolumn{7}{|c|}{$37^{\circ} \mathrm{C}$. } \\
\hline & $\begin{array}{l}\text { Sub- } \\
\text { stances } \\
\text { applied }\end{array}$ & $\begin{array}{l}\text { No. of } \\
\text { experi- } \\
\text { ments }\end{array}$ & $P_{0}$ & $P_{7}$ & $\mathbf{P}_{T}$ & $P_{2}-P_{0}$ & $\mathbf{P}_{T}-\mathbf{P}_{\boldsymbol{\eta}}$ & $\mathbf{A}$ & $\begin{array}{l}\text { No. of } \\
\text { experi- } \\
\text { ments }\end{array}$ & $P_{0}$ & $P_{2}$ & $\mathbf{P}_{\boldsymbol{T}}$ & $\mathrm{P}_{2}-\mathrm{P}_{0}$ & $\left|P_{T}-P_{7}\right|$ & $\mathbf{A}$ \\
\hline Actomyosin & $\begin{array}{l}\text { Water } \\
\text { Water } \\
\text { ATP* }\end{array}$ & $\begin{array}{r}22 \\
5 \\
9\end{array}$ & $\begin{array}{l}1 \cdot 20 \\
1.00 \\
2 \cdot 85\end{array}$ & $\begin{array}{l}2 \cdot 35 \\
2 \cdot 35 \\
5 \cdot 50\end{array}$ & $\begin{array}{l}4 \cdot 20 \\
4 \cdot 35 \\
7 \cdot 80\end{array}$ & $\begin{array}{l}1 \cdot 15 \\
1 \cdot 35 \\
2 \cdot 65\end{array}$ & $\begin{array}{l}1 \cdot 85 \\
2 \cdot 00 \\
2 \cdot 35\end{array}$ & $\begin{array}{l}11 \cdot 35 \\
11 \cdot 30 \\
14 \cdot 40\end{array}$ & $\begin{array}{r}15 \\
2 \\
13\end{array}$ & $\begin{array}{l}0.95 \\
1 \cdot 30 \\
4 \cdot 80\end{array}$ & $\begin{array}{l}2 \cdot 25 \\
2 \cdot 30 \\
8 \cdot 65\end{array}$ & $\begin{array}{r}4 \cdot 10 \\
5 \cdot 55 \\
12 \cdot 10\end{array}$ & $\begin{array}{l}1 \cdot 30 \\
1.00 \\
3 \cdot 85\end{array}$ & $\begin{array}{l}1 \cdot 85 \\
3 \cdot 25 \\
3 \cdot 45\end{array}$ & $\begin{array}{l}10 \cdot 20 \\
11.00 \\
17.05\end{array}$ \\
\hline $\begin{array}{l}\text { Actin-free } \\
\text { myosin }\end{array}$ & $\begin{array}{l}\text { Water } \\
\text { ATP }\end{array}$ & $\begin{array}{r}4 \\
10\end{array}$ & $\begin{array}{l}1 \cdot 15 \\
6 \cdot 25\end{array}$ & $\begin{array}{l}1 \cdot 90 \\
9 \cdot 35\end{array}$ & $\begin{array}{r}2 \cdot 85 \\
13 \cdot 95\end{array}$ & $\begin{array}{l}0 \cdot 75 \\
3 \cdot 10\end{array}$ & $\begin{array}{l}0 \cdot 95 \\
4 \cdot 60\end{array}$ & $\begin{array}{r}9 \cdot 20 \\
18 \cdot 15\end{array}$ & $\begin{array}{l}4 \\
8\end{array}$ & $\begin{array}{l}1 \cdot 60 \\
9 \cdot 20\end{array}$ & $\begin{array}{r}2 \cdot 35 \\
12 \cdot 30\end{array}$ & $\begin{array}{r}3 \cdot 95 \\
17 \cdot 10\end{array}$ & $\begin{array}{l}0 \cdot 75 \\
3 \cdot 10\end{array}$ & $\begin{array}{l}1 \cdot 60 \\
4 \cdot 80\end{array}$ & $\begin{array}{l}10 \cdot 55 \\
20 \cdot 30\end{array}$ \\
\hline $\begin{array}{l}\text { Actomyosin } \\
\text { with low ad- } \\
\text { enosine tri- } \\
\text { phosphatase } \\
\text { activity }\end{array}$ & $\begin{array}{c}\text { Water } \\
\text { ATP* } \\
\text { ATP }+^{*}+ \\
\text { KCl+ } \\
\mathrm{MgCl}_{2}+\end{array}$ & $\begin{array}{l}1 \\
2 \\
2\end{array}$ & $\begin{array}{r}1 \cdot 40 \\
5 \cdot 50 \\
11 \cdot 45\end{array}$ & $\begin{array}{r}2 \cdot 15 \\
7 \cdot 85 \\
13 \cdot 10\end{array}$ & $\begin{array}{r}4 \cdot 00 \\
12 \cdot 55 \\
20 \cdot 40\end{array}$ & $\begin{array}{l}0 \cdot 75 \\
2 \cdot 35 \\
1 \cdot 65\end{array}$ & $\begin{array}{l}1 \cdot 85 \\
4 \cdot 70 \\
7 \cdot 30\end{array}$ & & 2 & $6 \cdot 75$ & $9 \cdot 00$ & $16 \cdot 75$ & $2 \cdot 25$ & $7 \cdot 75$ & \\
\hline
\end{tabular}

* $2 \times 10^{-6} \mathrm{~mol} . / \mathrm{ml}$. adenosine triphosphate.

$\dagger 2 \times 10^{-6} \mathrm{~mol} / \mathrm{ml}$. adenosine triphosphate $+1 \times 10^{4} \mathrm{~mol} . / \mathrm{ml}$. potassium chloride $+1 \times 10^{-5} \mathrm{~mol} . / \mathrm{ml}$. magnesium chloride.

Actomyosin and actin-free myosin threads contain appreciable amounts of adenine, ribose and phosphorus which cannot be removed by repeated washing, but are extractable after denaturation. In the protein-free extracts the phosphorus is present as orthophosphate $\left(\mathbf{P}_{0}\right)$, readily hydrolysable phosphate $\left(\mathrm{P}_{7}-\mathrm{P}_{0}\right)$ and difficultly hydrolysable phosphate $\left(\mathrm{P}_{T}-\mathrm{P}_{7}\right)$.

Treatment with adenosine triphosphate causes a considerable increase in adenine, ribose and the different phosphate fractions, not removable by repeated washing (see table). The ratio of readily hydrolysable phosphate and phosphate hydrolysable with difficulty to adenine corresponds roughly to the ratio calculated for adenosine diphosphate.

The uptake of adenine, ribose and phosphate can be observed only after the application of adenosine triphosphate. No uptake of either nucleotide or phosphate follows treatment of the protein with adenosine diphosphate, adenylic acid, orthophosphate or pyrophosphate. The effect of adenosine triphosphate is independent of the adenosine triphosphatase activity of the protein, as threads from preparations with high and low enzymic activity give the $\operatorname{sam} \theta$ results. Inosine triphosphate and inorganic triphosphate, which are both split by adenosine triphosphatase, produce neither an uptake of nucleotide nor of phosphate. Furthermore, an increase in temperature from $0^{\circ} \mathrm{C}$. to $37^{\circ} \mathrm{C}$. is accompanied by a much higher increase in enzymic activity than in nucleotide and phosphate uptake.

The orthophosphate found in the protein-free extract must originate from highly labile phosphate bound to the protein, that is, it is the expression of a phosphorylation of the protein. It can scarcely be present as orthophosphate before denaturation, be-
Adenosine triphosphate causes phosphate and nucleotide uptake both in threads of actomyosin and actin-free myosin, whereas the constriction of volume occurs only in the presence of actin. Hence, the chemical changes must be localized in the myosin moiety of the protein.

Fritz BuchthaL

ADAM Deutsch

Gustav G. KNAPPEIS

Agnete Munch-Petersen

Institute of Neurophysiology,

University of Copenhagen.

Institute of Chemistry,

University of Lund. June 24.

${ }^{1}$ Kalckar, H. M., Chem. Rev., 28, 71 (1941).

${ }^{2}$ Szent-Györgyi, A., Acta Physiol. Scand., 8, Suppl. XXV (1945).

\section{Ribonucleic Acid Supply and Phosphatase Distribution during the Spermatogenesis of Asellus aquaticus}

STUDIEs on the spermatogenesis of Asellus aquaticus L. ${ }^{1}$ directed attention to the polyploid cells surrounding each testicular lobe. It has been found that these cells show cyclic variations of morphological characters both in nucleus and in cytoplasm which correspond to different phases of spermatocytic evolution. The latter is almost synchronous in each lobe, and a small bunch of spermatogonia remains in the basal portion of the lobe, to ensure the next spermatogenetic wave.

The nuclei of the surrounding cells are polyploid of the Gerris type ${ }^{2}$, that is, with chromosomes 